\title{
Encapsulation of Temulawak Extract by Using Nanocrystalline Cassava and Sago Starches and Maltodextrin
}

\author{
Titi Candra Sunarti ${ }^{*}$, Fatimah J. Pasaribu ${ }^{1}$, Christina Winarti ${ }^{2}$ \\ ${ }^{1}$ Department of Agroindustrial Technology, Bogor Agricultural University (IPB University), Indonesia \\ ${ }^{2}$ Indonesian Agency for Agricultural Research and Development, Bogor, Indonesia
}

\begin{abstract}
This study was conducted to evaluate the performance of Curcuma zanthorrhiza crude extract after encapsulated in nanocrystalline starch, and to investigate the effect of the ratio of nanocrystalline starches and maltodextrin; and the effect of concentration of temulawak extract on nanocapsule characteristics, as well as encapsulation effect on the stability of antioxidant activity. Preparation of nanocrystalline starch was conducted by using lintnerization and ethanol precipitation of cassava and sago starches. Nanocrystalline starch and maltodextrin were used as matrices with the ratio varied from 25:75, 50:50, and 75:25. The mixture of temulawak extract and matrices were homogenized and spray dried. Nanocapsules characteristics included the efficiency of encapsulation and drug loading, and antioxidant activity test were investigated. Nanocrystalline cassava and sago starches were potentially modified starch that can be used as the matrix for its low solubility and digestibility. It showed that the ratio of nanocrystalline starch, maltodextrin, and concentration of temulawak extract significantly influenced the nanocapsule characteristics. The best encapsulation condition obtained for nanocrystalline matrix from cassava starch with the ratio of nanocrystalline starch: maltodextrin $25: 75(\% \mathrm{w} / \mathrm{w})$ and $10 \%$ concentration of the temulawak extract, while for sago are $75: 25(\% \mathrm{w} / \mathrm{w})$ and $10 \%$ concentration of temulawak extract. Nanocrystalline matrix from cassava starch revealed higher encapsulation efficiency and antioxidant activity. The use of high temperatures during spray drying affected by the slight decline of antioxidant activity of encapsulated temulawak extract. Encapsulation of temulawak extract by using nanocrystalline starch and maltodextrin could retain and protect its antioxidant activity.
\end{abstract}

Keywords: encapsulation; maltodextrin; nanocrystalline starch; spray drying; temulawak extract

Email: titi-cs@apps.ipb.ac.id

\section{INTRODUCTION}

Temulawak (Curcuma zanthorrhiza) is one of the typical Indonesian plants that are widely used as herbal medicine because it contains curcumin, an active compound that is efficacious as the antioxidant, antiinflammatory, anti-cancer, anti-cholesterol, and for other diseases. Research and clinical studies on the benefits of curcumin have been widely reported by Dhillon et al. (2008), Garcia et al. (2007), Sharma et al. (2001), and Shoskes et al. (2005). Consumption of temulawak is currently presented in the form of crude temulawak extract or dried powder material. The absorption of curcumin active compound in the human body in the form of the crude extract is less effective because of the nature of curcumin itself, which has low bioavailability and insoluble in water. Besides that, curcumin has a high sensitivity to $\mathrm{pH}$, temperature, and light. Therefore, one way to overcome these weaknesses is to increase the solubility and bioavailability of curcumin and protect curcumin by encapsulating the curcumin with a suitable matrix.
Starch is widely used as an encapsulating agent because it has several advantages, including biodegradable and easy to be modified for improving its physicochemical characteristics. Starches have also long been used as additives to pharmaceutical preparations, either as fillers, stabilizers, or drug coating agent. However, the use of native starch as a matrix has some disadvantages such as insoluble in cold water, produce unstable suspension viscosity and high digestibility that does not match the desired matrix characteristics. Therefore, it is necessary to modify the starch by lintnerization, which eliminated the amorphous fraction of starch at the branching point of the amylopectin chains to become crystalline starch; to decrease starch digestibility, and reduce the size of starch to nano size (nanoparticles) through the process of precipitation.

According to Barros \& Stringheta (2006), the ideal encapsulation matrix must have a film-forming property, having an emulsifying property, biodegradable, gastrointestinal resistant, has a low viscosity at high concentrations, and indicating low hygroscopicity. 
However, it is not possible that all of these characteristics can be met by using a single matrix. Therefore, the mixing of two or more matrix components is more common. In the process of binding of water-insoluble curcumin-active compounds, the nanoparticle starch matrix requires additional help of another matrix that acts as a stabilizer and emulsifier, such as maltodextrin to produce stable nanocapsules. Maltodextrin is a modified starch that is produced from partial hydrolysis of starch. Maltodextrins have fast dispersibility, low hygroscopic properties, and strong film-forming ability and binding strength (Srihari et al., 2010). Due to its strong binding strength, maltodextrin was also used as a co-matrix in this study. Previously Winarti et al. (2014) have reported the application of sole nanoparticles from arrowroot starch as an encapsulation matrix for curcumin. In this study, the encapsulation was performed using sago and cassava nanoparticle starches as carrier matrix, with the addition of maltodextrin, which acts as a stabilizer and emulsifier.

\section{METHODS}

\section{Materials}

Cassava and sago starches used in this research were obtained from the local small-scale industry in Bogor, Indonesia. The crude extract of temulawak was kindly supplied from Indonesian Center for Agricultural Postharvest Research and Development and produced by using ethanol-extraction of dried Curcuma rhizome.

\section{Preparation and Characterization of Nanocrystalline Starch}

The nanocrystalline cassava and sago starches were prepared by two successive processes, i.e., lintnerization and ethanol precipitation, according to Winarti et al. (2014) methods. About 50\% of the starch slurry was dispersed in $2.2 \mathrm{~N}$ of $\mathrm{HCl}$ at $35^{\circ} \mathrm{C}$ and then incubated on shaking incubator at $120 \mathrm{rpm}$ for $6 \mathrm{~h}$. The slurry was neutralized by $1 \mathrm{~N}$ of $\mathrm{NaOH}$, then washed with distilled water and ethanol, and oven-dried at $40^{\circ} \mathrm{C}$ for overnight. The lintnerized starch was then completely gelatinized. Ethanol was added to the solution drop by drop with slow stirring. The precipitate then oven-dried at $40^{\circ} \mathrm{C}$ for overnight. Characterizations of nanocrystalline cassava and sago starches were determined for solubility and swelling power (Perez et al., 1999), and in vitro starch digestibility by using porcine pancreatin amylase (Anderson, et al., 2002).

\section{Process of Encapsulation of Curcumin Extract}

The procedure for the encapsulation process of curcumin extract was modified from Winarti et al. (2014). Each nanocrystalline starch was mixed with maltodextrin with different composition ratios (starch: maltodextrin 25:75, 50:50, and 75:25). About $15 \mathrm{~g}$ of both starchy materials were diluted in $150 \mathrm{ml}$ water to produce $10 \%$ of starch solution. The mixture was then dispersed and stirred at $70 \mathrm{oC}$ with a magnetic stirrer for 15 minutes, and then stood to rehydrate for overnight. $5 \%$ and $10 \%(\mathrm{v} / \mathrm{v})$ of crude temulawak extract, which had been diluted with ethanol with total dissolved solids $\sim 20$ oBrix, was mixed with a starch solution, and then homogenized with Ultra Turrax for 10 minutes at $11000 \mathrm{rpm}$. The next process was atomization and dried with a spray dryer with inlet temperature conditions around $80 \mathrm{oC}$ and outlet temperature $170^{\circ} \mathrm{C}$. The obtained nanocapsules were weighed and calculated its yield. Nanocapsules characteristics included the efficiency of encapsulation and drug loading (Herdini et al. 2010), and antioxidant activity was investigated by DPPH (1,1-diphenyl-2picrylhydrazyl-Sigma) assay. DPPH was a stable free radical. When the antioxidant reacted with DPPH, the antioxidant could donate a hydrogen atom, and then DPPH would convert to the reduced or nonradical form (Diphenylpicrylhydrazine). This could be monitored by the loss of the violet color to be a residual pale yellow color (Molyneux, 2004). The antioxidant activity was calculated as a percentage of antioxidant inhibition against free radical components.

\section{RESULTS}

Herb active ingredient like curcumin, generated from the rhizomes of Curcuma zanthorrhiza plant (local name Temulawak), was one of the materials used in traditional medicine.

\section{Characteristics of Nanocrystalline Starch}

The nanocrystalline starch was produced by two main processes, namely lintnerization and gelatinized starch precipitation. Lintnerization or slow acid hydrolysis

Table 1. Functional properties of nanocrystalline starch

\begin{tabular}{lll}
\hline Characteristics & Cassava Starch & Sago Starch \\
\hline Solubility (\%) & 72.78 & 56.67 \\
Swelling power (\%) & 226.38 & 249.15 \\
$\begin{array}{l}\text { Pancreatin amylase } \\
\text { digestibility (\%) }\end{array}$ & 71.67 & 80.25 \\
\hline
\end{tabular}


Table 2. Characteristics of nanocapsules

\begin{tabular}{|c|c|c|c|c|c|c|c|}
\hline \multirow{3}{*}{ Characteristics } & \multirow{3}{*}{$\begin{array}{l}\text { Temulawak } \\
\text { Extract (\% } \\
\text { v/v) }\end{array}$} & \multicolumn{6}{|c|}{ Matrices Ratio (Nanocrystalline Starch: Maltodextrin) } \\
\hline & & \multicolumn{3}{|c|}{ Cassava Starch } & \multicolumn{3}{|c|}{ Sago Starch } \\
\hline & & $25: 75$ & $50: 50$ & $75: 25$ & $25: 75$ & $50: 50$ & $75: 25$ \\
\hline \multirow{2}{*}{ Yield $(\%)$} & 5 & 32.75 & 34.64 & 35.52 & 31.46 & 30.02 & 37.52 \\
\hline & 10 & 37.73 & 37.64 & 36.95 & 43.62 & 44.13 & 33.19 \\
\hline \multirow{2}{*}{ Encapsulation Efficiency (\%) } & 5 & $56.28 \pm 4.45$ & $69.95 \pm 2.81$ & $32.89 \pm 13.54$ & $58.54 \pm 0.18$ & $52.78 \pm 2.82$ & $43.52 \pm 3.35$ \\
\hline & 10 & $69.78 \pm 1.13$ & $47.15 \pm 0.50$ & $37.18 \pm 5.63$ & $25.03 \pm 14.90$ & $37.31 \pm 1.02$ & $45.71 \pm 3.98$ \\
\hline \multirow{2}{*}{ Drug loading (\%) } & 5 & $0.14 \pm 0.00$ & $0.16 \pm 0.01$ & $0.14 \pm 0.00$ & $0.14 \pm 0.00$ & $0.15 \pm 0.01$ & $0.15 \pm 0.01$ \\
\hline & 10 & $0.24 \pm 0.02$ & $0.20 \pm 0.01$ & $0.18 \pm 0.01$ & $0.22 \pm 0.01$ & $0.25 \pm 0.03$ & $0.28 \pm 0.01$ \\
\hline \multirow{2}{*}{ Antioxidant Activity (\%) } & 5 & $32.76 \pm 1.45$ & $34.09 \pm 5.50$ & $39.29 \pm 2.60$ & $20.19 \pm 2.07$ & $31.30 \pm 1.82$ & $31.09 \pm 2.12$ \\
\hline & 10 & $85.25 \pm 0.11$ & $85.07 \pm 2.14$ & $82.79 \pm 0.66$ & $52.60 \pm 1.31$ & $59.38 \pm 1.03$ & $61.47 \pm 0.77$ \\
\hline
\end{tabular}

data presented in mean + - standard deviation, except for the yield 
removed the amorphous parts of starch, and left the crystalline starch known as Lintnerized starch. Ethanolprecipitation of gelatinized-lintnerized starch would reduce the size from micrometer into nano-sized particles, as well as the changes in its characteristics. The values of solubility, swelling power, and digestibility of cassava and nanocrystalline sago starch were shown in Table 1. The solubility value $(57 \%)$ of sago nanocrystalline starch was lower than that of cassava starch $(73 \%)$, but nanocrystalline sago starch had higher swelling power $(249 \%)$ and in vitro digestibility $(80 \%)$.

\section{Characteristics of Nanocapsules}

Curcumin was insoluble in the water and had a high sensitivity to $\mathrm{pH}$, temperature, and light. Incorporation of curcumin into the nano-starch matrix would enhance its solubility and bioavailability, as well as protects from environmental deterioration. The characteristic of nanocapsules of the temulawak extract was shown in Table 2. The yield for nanocapsule of temulawak extract with cassava nanocrystalline starch was $32.75-37.64 \%$, while nanocrystalline sago starch was $30.02-44.13 \%$.

The encapsulation efficiency (EE) showed the number of active ingredients bound in the matrix calculated from the amount of active ingredient added before the encapsulation process. The results showed EE nanocapsule matrix of nanocrystalline tapioca starch of $32.89-69.95 \%$, and in nanocrystalline sago matrix of $33.19-58.54 \%$.

The capability of the starch matrix to encapsulate the active compound could be determined by drug loading (DL) value. The results showed that the drug loading of the nanocapsule matrix from nanocrystalline tapioca was $0.14-0.24 \%$, while the nanocrystalline sago matrix was $0.14-0.28 \%$. Both matrices have a high capability to encapsulate active compounds. The matrices can increase the encapsulated of active compounds from $10 \%$ of temulawak extract (DL $0.18-0.28 \%$ ) compared to lower $(5 \%)$ concentration (DL 0.14-0.16\%). The highest DL produced at $10 \%$ temulawak extract concentration. It was found that the matrix with $75 \%$ ratio of nanocrystalline sago starch and $25 \%$ maltodextrin produced DL with the highest mean value. In the formulation, the ratio of sago nanocrystalline starch: maltodextrin 75: 25 and concentration of temulawak extract $10 \%$, revealed a DL value of $0.28 \pm 0.01 \%$.

Measurement of antioxidant activity was generally conducted to evaluate the presence of oxidation inhibition activity by antioxidant compounds contained in temulawak extracts. The results (Table 2) showed that the antioxidant activity produced by nanocapsule nanocrystalline tapioca matrices were $32.76-85.25 \%$, higher compared to sago matrices (20.19-61.47\%). The value of antioxidant activity was correlated to DL value. E-ISSN 2477-0612
The results showed that $10 \%$ of temulawak extract gave higher (more than twice) antioxidant activity compared to $5 \%$. The best antioxidant activity was produced by nanocapsule with the addition of $10 \%$ temulawak extract. The increased concentration of added temulawak extract caused the increment of encapsulated curcumin active compound so that more DPPH compounds could be reduced.

\section{DISCUSSION}

The nanocrystalline starch is a modified native starch that was having a particle size of $20-50 \mathrm{~nm}$ and has crystalline properties. Starches could form nanostructures because the starch granules themselves were composed of nanoscale crystalline blocks with a diameter of 20-500 nm, depending on the botanical origin. A granular block was composed of layers consisting of crystalline lamellae (5-6 nm) and amorphous lamellae (2-5 nm) (Gallant et al., 1997).

The nanocrystalline starch was produced by two main processes, namely lintnerization and starch precipitation. Lintnerized starch produces crystalline starch, a modified starch which had been cleavaged its long-chain amylose fraction and its branching point $\alpha-1.6$ inter clusters of amylopectin chains, to produce short-chain amylose fraction with lower molecular weight and to form the crystalline structure by hydrolysis using the strong acid. The more structures that were cleavaged into simple sugars, resulting in lower starch digestibility. Winterization also aimed to reduce the viscosity of starch and increase its crystallinity (Srichuwong et al., 2005).

The precipitation process was conducted by slowly adding organic solvents with rapid stirring. The formation of starch nanoparticles occurred when the starch was subjected to high-temperature treatment during the gelatinization process and the presence of mechanical agitation resulting in the destruction of covalent and hydrogen bonds in the double helix structure of amylopectin and melting of the crystalline part, resulting in smaller particles up to nano size (Winarti et al., 2014). It was reported that starch nanoparticles produced by ethanol precipitation processes were ranged between $100-250 \mathrm{~nm}$.

Based on Winarti et al. (2014), the solubility value of nanocrystalline starch was lower than crystalline (lintnerized) starch. Increasing the solubility in lintnerization due to hydrolysis process had damaged the granules and broke down the long starch chains into short chains, made it more easily dissolved. The solubility of nanocrystalline starch decreased due to the loss of water molecules and ethanol precipitation particles. Ethanol would replace the water molecules inside the material so that the solubility tends to be low. 
Factors such as amylose-amylopectin ratio, amylose content, and starch crystallinity influenced to swelling power and solubility properties. Swelling or waterabsorption capacity in starch was essential in biomedical or pharmaceutical applications, both as implants and drug delivery systems. This was because the level of the swelling equilibrium affected the solvent diffusion coefficient across the matrix, surface properties, and surface mobility, including its mechanical properties (Pepas et al., 1996).

Encapsulation of water-insoluble active compounds in the starch matrix was having difficulties in producing an excellent mixture. Table 2 showed that 50:50 ratio of nanocrystalline cassava starch and maltodextrin could produce high EE (69.95\%) with 5\%. In this condition, maltodextrin also acted as an emulsifier. This result was similar to that reported by Paramera et al. (2011), which encapsulated curcumin by using modified starch OSA (EE value $60.4 \%$ ) and with the addition of emulsifier (Tween 80 ) and 56.2\% for treatment without emulsifier (Paramera et al., 2011). Other studies reported by Winarti et al. (2014) produced nanocapsule with EE of 48.69$69.59 \%$ using nanoparticle arrowroot starch. Increasing the emulsifier concentrations resulted in smaller average particle size of nanocapsule (Mirjazani et al., 2010). This caused by the binding of the active compound in the matrix due to its higher active surface area. In this research, maltodextrins are also functioned as co-matrix, thereby increasing the suspension viscosity caused by preventing the migration of the active compounds from the dispersed phase limit (Rafati et al., 1997).

The resulting drug loading (Table 2) was relatively low (0.14-0.28), compared to the Paramera et al. (2011) as $2.8-2.9 \%$. The matrix with $75 \%$ ratio of nanocrystalline sago starch and $25 \%$ maltodextrin produced DL with the highest mean value. In the formulation, the ratio of sago nanocrystalline starch: maltodextrin 75:25 and the concentration of temulawak extract $10 \%$, revealed DL value of $0.28 \pm 0.01 \%$.

The highest DL produced at $10 \%$ temulawak extract concentration compared to $5 \%$ concentration. These results followed a similar trend with Lin et al. (2009) research, which showed a higher amount of encapsulated curcumin with increasing added concentration of curcumin. The amount of active compound loaded into the matrix would influence the antioxidant activity. The extract not only bound inside the matrix but also adsorbed on the matrix surface. Antioxidant activity was needed to determine the quality of antioxidants and product stability during processing and storage, as well as its implications to the human body. Wang et al. (2009) reported the levels of curcumin obtained after encapsulation, which decreased activity occurred very little or tended to be stable despite the heat treatment with high temperature $\left(80-100^{\circ} \mathrm{C}\right)$ and long heating time (10-50 minutes) (Wang et al., 2009). The encapsulation process would increase the resistance of the active compounds to heat (Paramera et al., 2011).

\section{CONCLUSION}

Nanocrystalline starch from both cassava and sago starches mixed with maltodextrin could be used to encapsulate the curcumin extract and could protect and maintain parts of its activity. The ratio of $25 \%$ of cassava nanocrystalline starch and $75 \%$ of sago nanocrystalline starch mixed with $25 \%$ and $75 \%$ of maltodextrin, respectively, could produce nanocapsules with highest encapsulation efficiency, drug loading, and antioxidant activity.

\section{ACKNOWLEDGMENT}

This research was financially supported by the Indonesian Agency for Agricultural Research and Development, Ministry of Agriculture through Program KKP3T Fiscal year 2012-2013.

\section{REFERENCES}

Anderson, A.K., Guraya, H.S., James, C., \& Salvaggio, L. 2002. Digestibility and pasting properties of rice starch heat-moisture treated at the melting temperature $\left(\mathrm{t}_{\mathrm{m}}\right)$. Starch, 54, 401-409.

Barros, F.A.R.D \& Stringheta, P.C. 2006. Microencapsulamento de antocianinas - uma alternativa para o aumento de sua aplicabilidade como ingrediente alimentício. Biotecnologia Ciência e Desenvolvimento, $36,18-24$.

Dhillon, N., Anggarwal, B.B., Newman, R.A., Wolff, R.A., Kunnumakkara, A.B., Abbruzzese, J.L., Ng, C.S., Badmaev, V., \& Kurzrock, R. (2008). Phase II clinical trial of curcumin in patients with advanced pancreatic cancer. Journal of Clinical Oncology, 24(18), 141-151.

Gallant, D., Bouchet, B., \& Baldwin, P. 1997. Microscopy of starch: evidence of a new level of granule organization. Carbohydrate Polymer, 60, 379-389.

Garcia, A.M., Borrelli, L.A, Rozkalne, A., Hyman, B.T., \& Bacskai, B.J. 2007. Curcumin labels amyloid pathology in vivo, disrupts existing plaques, and partially rest.ores distorted neurites in an Alzheimer mouse model. Journal of Neurochemistry, 102, 1095-1104.

Herdini, Darusman, L.K., \& Sugita, P. 2010. Disolusi mikroenkapsulasi kurkumin tersalut gel kitosan-alginat- 
glutaraldehida. Jurnal Makara Sains, 14(1), 57-62.

Lin, C.C., Lin, H.Y., Chen, H.C., Yu, M.W., \& Lee, M.H. 2009. Stability and characterization of phospholipidbased curcumin-encapsulated microemulsions. Journal of Food Chemistry, 116, 923-928.

Mirjazani F., Rafati, H., \& Atyabi, F. 2010. Fabrication of biodegradable poly(d,1-lactide-co- glycolide) nanoparticles containing tamoxifen citrate. Iranian Polymer Journal, 19(6), 437-446.

Molyneux, P. (2004). The use of the stable free radical diphenylpicrylhydrazyl (DPPH) for estimating antioxidant activity. Songklanakarin Journal of Science and Technology, 26(2), 211-219.

Paramera, E.I., Konteles, S.J., \& Karathanos, V.T. 2011. Stability and release properties of curcumin encapsulated in Saccharomyces cerevisiae, ß-cyclodextrin, and modified starch. Journal of Food Chemistry, 125, 913922.

Peppas, N.A., Vakkalanka, S., Brazel, C.S., Luttrell, A.S., \& Mongia, N.K. 1996. Controlled release system using swellable random and block copolymers and terpolymers. In Ogata, N., Kim, S.W., Feijen, J., Okano, T. Editor. Advance Biomaterials in Biomedical Engineering and Drug Delivery System, Springer. pp 3-6.

Perez, L.A.B., Acevedo, E.A., Hernandez, L.S., \& Lopez, O.P. 1999. Isolation and partial characterization of banana starch. Journal of Agriculture and Food Chemistry, 47, 854-857.

Rafati, H., Coombes, A.G.A., Adler, J., Holland, J., \& Davis, S.S. 1997. Protein-loaded poly (d,1-lactideco-glycolide) microparticles for oral administration: formulation, structural and release characteristics. Journal of Controlled Release, 43, 89-102.
Sharma, R.A., McLelland, H.R., Hill, K.A., Ireson, C.R., Euden, S.A., Manson, M.M., Pirmohamed, M., Marnett, L.J., Gescher, A.J., \& Steward, W.P. 2001. Pharmacodynamics and pharmacokinetic study of oral Curcuma extract in patients with colorectal cancer. Clinical Cancer Research, 7, 1894-1900.

Shoskes, D., Lapierre, C., Cruz-Correa, M., Muruve, N., Rosario, R., Fromkin, B., Braun, M., \& Copley, J. 2005. Beneficial effects of the bioflavonoids curcumin and quercetin on early function incadaveric renal transplantation: a randomized placebo controlled trial. Transplantation, 80, 1556-1559

Srichuwong, S., Sunarti, T.C., Mishima, T., Isono, N., \& Hisamatsu, M. 2005. Starches from different botanical sources I: Contribution of amylopectin fine structure to thermal properties and enzyme digestibility. Carbohydrate Polymer, 60, 529-538.

Srihari, E., Lingganingrum, F.S., Hervita, R., \& Wijaya, H. 2010. Pengaruh penambahan maltodekstrin pada pembuatan santan kelapa bubuk. Seminar Rekayasa Kimia dan Proses. ISSN : 1411- 4216. Universitas Diponegoro Semarang.

Wang, Y., Lu, Z., Lv, F., \& Bie, X. 2009. Study on microencapsulation of curcumin pigments by spray drying. European Food Research and Technology, 229, 391-396.

Winarti, C., Sunarti, T.C., Mangunwidjaja, D., \& Richana, N. 2014. Preparation of arrowroot starch nanoparticles by butanol-complex precipitation, and its application as bioactive encapsulation matrix. International Food Research Journal, 21(6), 2207-2213. 